\title{
Does Auditing Committee Characteristics Enhance Corporate Value? Evidence From Jordan
}

\author{
Ashraf Bataineh $^{1} \&$ Mustafa M Soumadi ${ }^{1}$ \\ ${ }^{1}$ Department of Financial and Administrative Sciences, AL-Balqa Applied University/Irbid University College, \\ Jordan \\ Correspondence: Dr. Ashraf Bataineh, Department of Financial and Administrative Sciences, AL-Balqa Applied \\ University/ Irbid University College, Jordan.
}

Received: January 14, 2020

Accepted: February 11, 2020

Online Published: March 17, 2020

doi:10.5430/ijfr.v11n2p348

URL: https://doi.org/10.5430/ijfr.v11n2p348

\begin{abstract}
The study aims to investigate the effect of auditing committee characteristics, represented in the auditing committee characteristics (size, independence, activity, financial expertise) on the enhancement of corporate value, for a sample of 47 Jordanian industrial companies listed at Amman Stock Exchange (ASE) during the period of (2014-2018). To achieve this goal, corporate value was measured using the return on assets (ROA) in addition to using the Pooled Data Regression. Study found a positive relationship between the auditing committee characteristics (size, activities, independence) and corporate value in the Jordanian industrial Companies, but didn't find a positive relationship between the financial expertise variable of auditing committee and the corporate value. Based on the study results, researchers made a number of recommendations that include: researchers and academic staffs must study in the future researches some of the other variables, such as the diversity of management committee, disclosure, transparency, and auditing fees in order to enhance corporate value.
\end{abstract}

Keywords: auditing committee characteristics, Jordanian industrial companies, corporate value, Amman Stock Exchange (ASE)

\section{Introduction}

The focus on corporate governance have been renewed during the last 30 years, pushed mainly by the collapse of several high-status companies, which found to hold either fragile or unsuccessful governance structures. The common international reaction to deal with this problem was the formulation of tighter governance structures in order to avoid the undesirable behaviors and increase corporate external transparency, with the fact that auditing committees have been recognized as an influential source of corporate governance's enhancement (Ghafran \& O'Sullivan, 2013). Therefore, the auditing committee received the attention of many countries in the world, especially after the recommendations of specialized scientific organizations, researchers, and academic staffs to create this committee, due to the important role it play in auditing the financial reports preparation processes, ensure its credibility, and also its involvement in supporting the independency of auditing process, which encouraged many countries to pass mandatory legislation that require companies to create auditing committees (Krishnan, 2005).

The successive governance reports in the United Kingdom have aimed to formulate the preliminary recommendations of Cadbury Committee (1992) which focus on the enhancement of auditing committee, in term of its independency, size, and financial expertise (Financial Reporting Council, 2008). This required from the auditing committees to not only interpret duties and rules to all companies listed on the stock exchange and to make sure of their compliance with them, but to ensure a high degree of consistency in the creation and governance of auditing committees.

The U.S witnessed the formation of Sarbanes-Oxley Act, by the Congress in July 2002 and the implementation of new corporate governance rules by Securities and Exchange Commission (SEC), in 2003 to check and handle the listed companies. The new corporate governance regulations place larger emphasis on firm's management independence, and on the board of directors and auditing committees' efficiency (Al-Matari, et al., 2014b; Aldamen, et al., 2012 \& Persons, 2005).

In Jordan, as a result of the significance role played by Auditing Committee to complete its tasks, the Stock 
Exchange Act $(76 ; 2002)$, which obligates all Jordanian companies to establish an Auditing Committee that contain at least three non-executive members of the Board of Directors. It requires from Auditing Committee to be in compliance with the instructions issued by Board of Directors, which align with the article (46) and contain a number of characteristics in its members, to enable them to do their businesses efficiently and effectively. The most important of those characteristics independence, professional experience, qualifications, number of members, and number of meetings to enable them enhance company's value (Reidenbach, 2013 \& Felo, et al, 2003).

The study aimed to investigate the formation and structure of auditing committees on a sample of (47) Jordanian industrial companies listed on the ASE, and how they affect Corporate Value. Specifically, we focus on the auditing committee size, independence degree, members' financial experience, and number of meetings. In addition, study will examine whether company's formation, size, level of scrutiny, financial expertise, and ability of auditing committee members will go toward the enhancement of corporate value.

This study can be distinguish from the previous studies in the fact that it dealt with the auditing committee characteristics collectively (size, accounting experience, number of meetings, and independency), which differ from the studies (Afza \& Nazir, 2014) \& (Kallamu, et al., 2015) that addressed some of the auditing committee characteristics, such as size, independency, and number of meetings but didn't take these characteristics jointly. This study measured the impact level of auditing committee characteristics on improving the companies' values, especially the industrial companies which consider the economical asset and contributor of the Hashemite Kingdom of Jordan government.

\section{Literature Review \& Hypotheses Development}

Auditing committee can play a significant role in the internal and external auditing, risk management, and financial reporting process, where affective auditing committee can reduce agency conflicts, safeguard shareholder's rights, and solve their issues and as a result enhance firm's value (Afza \& Nazir, 2014). The following are some of the studies that provide evidence that auditing committee characteristics improve company's performance:

\subsection{Auditing Committee Size}

DakhlAllah, et al, (2020) study results indicate that auditing committee size has a positive and significant relationship on the firm performance, and also several researchers like (Walker, 2004) revealed that auditing committee size, independence, and meeting rate may have effect on its screening process, where some researchers suggest the smaller the size of auditing committee the larger its monitoring effectiveness (Al-Matari, et al., 2012 \& Aldamen, et al., 2012). These studies goes with the agency theory which implies that small committees are more efficient as they have the tendency to not experience coordination and/or communication problems, but according to the resource dependence theory (Ghosh, et al., 2010; Beasley \& Salterio, 2001), declared that larger auditing committees tend to be better in monitoring due to their extensive skills and knowledge. Therefore on the basis of this supportive argument, the following hypothesis was developed:

H1: There is a significant positive relationship between auditing committee size and the corporate value enhancement.

\subsection{Auditing Committee Independence}

Kallamu, et al., (2015) study found a significant positive relationship between the independent auditing committee members and the profitability. The result supports agency theory which suggests that independent directors provide effective monitoring of management and as a result it will enhance profitability and reduce the possibility of opportunistic behaviour by the management and eventually lead to performance improvement. Chan \& $\mathrm{Li}(2008)$ clarified that self-governing professionals on the auditing committee have major role in corporate value enhancement, despite the fact that lots of researchers didn't find a relationship between auditing committee independence and unrestricted accumulations (Xie, et al., 2003; Be'dard, et al., 2004). Some earlier studies stated that large proportion of independent directors are capable of enhancing corporate performance (Fama \& Jensen, 1983), while Chen, et al., (2008) used TQ to measure the positive relationship between auditing committee independence and corporate performance, and also Ilona (2008) got a similar result using ROA to measure the relationship between auditing committee independence and corporate performance. Therefore on the basis of the above discussion, the following hypothesis was developed:

$\mathrm{H} 2$ : There is a significant positive relationship between auditing committee independence and the corporate value enhancement. 


\subsection{Auditing Committee Activities}

Al-Farooque, et al., (2019) study found that auditing committee meetings show significant explanatory power on market-based firm's performance at Thai firms. Sharma, et al. (2009) also proposed that any increase in auditing committee meetings will lead to a positive impact on corporate performance, while (Choi, et al., 2013) studied the impact of auditing committee characteristics on corporate performance in Greece, and found a positive relationship between number of meetings and corporate performance. Ismail, et al, (2008) sees that auditing committee meetings are an important tool to verify that committee members complete the tasks assigned to them toward the company, also (Bedard, et al., 2004) sees that auditing committees must carry out tasks efficiently through increasing the frequent meetings, in order to maintain the controlling process, but still we believe that frequent meetings of auditing committee is a good indicator on its effectiveness.

Therefore on the basis of the above discussion, the following hypothesis was developed:

H3: There is a significant positive relationship between auditing committee activities and the corporate value enhancement.

\subsection{Auditing Committee Financial Expertise}

DakhlAllah, et al, (2020) study results demonstrate that financial expertises of the auditing committee have a positive and significant relationship on the firm performance. Also most of corporate governance rules and regulations require hiring not less than one accounting and financial expert, as an auditing committee member, where literature stated that experts on auditing committee considerably enhance its effectiveness, and also provided the empirical evidences that support the positive impact of auditing committee expertise. For example, (Xie, et al., 2003; Abbott, et al., 2004; Soliman \& Ragab, 2014) did find that auditing committee expertise decreases the earnings management and financial reporting restatements, while (DeZoort, et al., 2003) indicated that experience and knowledge of auditing committee members is important to help them deal with the external auditors, adding that auditing committee members and especially those who hold the essential professional certifications, such as CPA understand the responsibilities and duties of auditors more than their counterparts. Therefore on the basis of the above discussion, the following hypothesis was developed:

H4: There is a significant positive relationship between auditing committee financial expertise and the corporate value enhancement.

\section{Theoretical Framework}

\subsection{Auditing Committee Characteristics}

Auditing committees' concepts vary in accordance with the goals, responsibilities, and functions that are assigned to them, where Al-Thuneibat (2006) defined it as the committee which made up of non-executive directors in the corporate, while (Arens, et al., 2009) defined it as a group of individuals who are selected from the board of directors to be accountable for maintaining the auditor independency.

According to the rules of corporate governance, auditing committees should be independent and perform their responsibilities using their expertise, where this auditing committee should be hold responsible for the financial manipulation, whereas the clearness of financial information should decrease information unevenness and enhances corporate value (Bhagat \& Jefferis, 2002; Heenetigala \& Armstrong, 2011).

\subsection{Corporate Value}

Auditing committees have been observed as a complementary to the financial reporting quality; where corporate create auditing committees to enhance the quality and practice levels, and earnings ratios of financial reporting (Ramsay, 2001). The basic jobs of auditing committee are to manage the financial reporting process, and watch the managers' inclination to manipulate earnings, where in recent years regulators have questioned the auditing committee's effectiveness to ensure that financial statements are reasonably declared without earnings management. Corporate Governance Reforms in many countries have authorized the auditing committee to control the financial reporting, due to the failure of many companies lately (Sarbanes-Oxley Act, 2002; Smith, 2003). Hypothetically, it should be anticipated that a successful auditing committee with governance characteristics would enhance the corporate value.

There are a variety of reliable standards and criteria that can be used to measure corporate value, the first group is accounting standards which depend on the accounting and financial information derived from the corporate financial statements, and include ROA, EPS, and interest coverage ratio, while the second group is economic measures, such as added value measurements, and the third group deals with the market standards and includes measurements like 
Tobin $\mathrm{Q}$ ratio, and the ratio of market value to book value. Accounting standards represented in ROA method consider one of the most used criteria to measure the corporate value in accounting (Al-Matari, et al., 2014; Afza \& Nazir, 2014; Al-Karasneh \& Bataineh, 2018).

\subsection{Auditing Committees in Jordanian Companies}

The Hashemite Kingdom of Jordan outlined several legislations to support corporate governance, such as the stock exchange law (No.76; 2002), which require from all Jordanian joint-stock companies to set up an auditing committee that consist of three non-executive members from the company's board of directors. The tasks and roles of such committee are decided according to the instructions issued by the board of directors, which comply with the article (46). The article (No.1; 1998) was issued by the ASE and commanded all the Jordanian joint-stock companies to create an auditing committee, where modern disclosure instructions were issued and put into effect at the beginning of 2004. But Article (No. 15) described the way corporate may use to create an auditing committee, defining in it the tasks and responsibilities of its members. In Jordan, ASE was the first party to issue an auditing committee's concept, as a directory of governance rules for the companies listed in ASE, 2008, which requires that auditing committee should contain not less than three non-executive members of the board of directors, where two of them have to be at least independent members, and the other chairs of the committee, and also all committee's members should have knowledge about the financial and accounting issues (Hamdan, et al., 2012).

\section{Data \& Methodology}

\subsection{Sample Characteristics \& Data Collection}

Data were collected from the yearly reports of all Jordanian industrial companies listed in Amman Stock Exchange (ASE) during the period (2014-2018) (www.ase.com.jo/2019), and these companies represented a clear society for this study, where this sector was selected due to its significance in supporting the Jordanian economy (Bataineh, 2018), and the number of listed companies in this sector amounted to (52) companies by the end of (2018). Researcher developed several conditions to select the study sample, which are: All required data to calculate the study variables must be available about the companies in the study sample, and these companies must not be merged with other companies or suspended from trading during the study period (2014-2018), where the number of companies that met these conditions were (47) companies. The following table illustrates the study population and the procedures used to select the study sample:

Table 1. Study population \& procedures used to select the sample

\begin{tabular}{llll}
\hline Industrial Companies Sector & Study Population & Exempted Companies & Study Sample \\
\hline Textile, clothing, and leather industry & 3 & 0 & 3 \\
\hline Electrical industries & 3 & 0 & 3 \\
\hline Engineering \& construction industries & 9 & 1 & 8 \\
\hline Extractive \& mining industries & 11 & 1 & 10 \\
\hline Tobacco and cigarettes industries & 2 & 0 & 2 \\
\hline Food and beverage industry & 10 & 2 & 8 \\
\hline Chemical industries & 10 & 1 & 8 \\
\hline Pharmaceutical industry & 4 & 0 & 4 \\
\hline Total & 52 & 5 & 47 \\
\hline
\end{tabular}

Regression analysis employed to examine the impact of auditing committee characteristics on the corporate value enhancement, where corporate size and leverage are included as control variables.

The regression represented in the following equation:

$$
\mathrm{ROA}=\alpha+\beta 1 \mathrm{AC}_{\mathrm{SIZE}}+\beta 2 \mathrm{AC}_{\mathrm{IND}}+\beta 3 \mathrm{AC}_{\mathrm{ACTIV}}+\beta 4 \mathrm{AC}_{\mathrm{EXPE}}+\beta 5 \mathrm{~F}_{\mathrm{SIZE}}+\beta 6 \mathrm{LEV}+\varepsilon
$$


Table 2. Summary of variables measurement

\begin{tabular}{|c|c|c|}
\hline Variables & Acronym & Operationalization \\
\hline \multicolumn{3}{|l|}{ Dependent Variables (DV) } \\
\hline Return on Assets (\%) & ROA & Net income / Total assets \\
\hline \multicolumn{3}{|l|}{ Independent Variables (IV) } \\
\hline Auditing Committee Size (number) & $\mathrm{AC}_{\text {SIZE }}$ & Total number of members serving on the $\mathrm{AC}$ \\
\hline Auditing Committee Independence (\%) & $\mathrm{AC}_{\mathrm{IND}}$ & Proportion of independent directors on the AC \\
\hline Auditing Committee Activity (number) & $\mathrm{AC}_{\mathrm{ACTIV}}$ & Number of AC meetings in the year \\
\hline $\begin{array}{l}\text { Auditing Committee financial Expertise } \\
(\%)\end{array}$ & $\mathrm{AC}_{\text {EXPER }}$ & $\begin{array}{l}\text { Number of members who hold a scientific degree in } \\
\text { accounting or finance/Total members }\end{array}$ \\
\hline \multicolumn{3}{|l|}{ Controlling Variables (CV) } \\
\hline Firm Size (Log) & $\mathrm{F}_{\text {SIZE }}$ & The natural logarithm of total assets \\
\hline Leverage $(\%)$ & LEV & Total Liabilities / Total assets \\
\hline
\end{tabular}

\subsection{Data Analysis \& Results}

The descriptive statistics, correlation matrix, and multivariate regression were used in this study to test the research model. Multivariate regression was implemented after ensuring first that a number of assumptions had been met.

\subsubsection{Descriptive Statistic}

It used in the regression model of study variables to analyze the relationship between auditing committee characteristics and the variables of corporate value, and the results of continuous variables presented in Table ), which include mean, standard deviation, min \& max that are calculated through SPSS, Version 21.

Table 3. Descriptive statistics of all variables

\begin{tabular}{llllll}
\hline Variables & Unit & Mean & STDEV & Min & Max \\
\hline $\mathbf{A C}_{\text {SIZE }}$ & Number & 3.85 & 1.37 & 3.00 & 9.00 \\
\hline $\mathbf{A C}_{\text {IND }}$ & Ratio & 0.58 & 4.97 & 0.00 & 0.75 \\
\hline $\mathbf{A C}_{\text {ACTIV }}$ & Number & 4.01 & 1.34 & 3.00 & 8.00 \\
\hline $\mathbf{A C _ { \text { EXPER } }}$ & Ratio & 0.46 & 0.25 & 0.11 & 1.00 \\
\hline $\mathbf{F}_{\text {SIZE }}$ & Log & 12.24 & 1.51 & 2.05 & 17.35 \\
\hline $\mathbf{L E V}$ & Ratio & 45.62 & 41.61 & 0.41 & 366.03 \\
\hline $\mathbf{R O A}$ & Ratio & 3.12 & 2.28 & 0.19 & 11.03 \\
\hline
\end{tabular}

Table 3 above shows that auditing committee size ranges between (3-9) members, with an arithmetic mean of (3.85) and a standard deviation of (1.37), and showed that (58\%) from the non-executive directors or independent are present in the auditing committees of Jordanian companies, where the auditing committees of sample companies meet from 3 to 8 times a year, with an average of 4 meetings per year. For auditing committee experts, study show that $(46 \%)$ of auditing committees members at the Jordanian industrial companies have financial and accounting expertise. The descriptive statistics revealed that most Jordanian industrial companies meet the criteria stated in stock exchange law (No. 76; 2002), where the table statistics showed that on an average the auditing committees consist of (3) members and meet no less than (3) times a year, and the majority of these companies have independent members and are auditing by senior auditors in Jordan. In addition, corporate sample showed that arithmetic mean of return on assets variable is (3.12) with standard deviation of (2.28), where the average of ROA companies are (1,391) millions.

\subsubsection{Correlation Matrix}

A group of tests were used to examine the strength of multiple linear regression models, and the first was to test the 
independency of independent variables, where Pearson correlation coefficients matrix was calculated to identify the relationship between independent variables, in order to detect the presence of linear correlation between the independent variables. Table (4) shows the results of correlations coefficients between variables:

Table 4. Results of Pearson correlation coefficients analysis

\begin{tabular}{llllllll}
\hline & ROA & $\mathbf{A C}_{\text {SIZE }}$ & $\mathbf{A C}_{\text {INDE }}$ & $\mathbf{A C}_{\text {ACTIV }}$ & $\mathbf{A C}_{\text {EXPE }}$ & $\mathbf{F}_{\text {SIZE }}$ & LEV \\
\hline $\mathbf{R O A}$ & 1 & & & & & & \\
\hline $\mathbf{A C}_{\text {SIZE }}$ & $0.466^{* *}$ & 1 & & & & & \\
\hline $\mathbf{A C}_{\text {INDE }}$ & $0.220^{* *}$ & $0.162^{*}$ & 1 & & & & \\
\hline $\mathbf{A C}_{\text {ACTIV }}$ & $0.433^{* *}$ & $0.787^{* *}$ & $0.157^{*}$ & 1 & & & \\
\hline $\mathbf{A C}_{\text {EXPE }}$ & $-0.161^{*}$ & $-0.351^{* *}$ & -0.067 & $-0.160^{*}$ & 1 & & \\
\hline $\mathbf{F}_{\text {SIZE }}$ & $0.439^{* *}$ & $0.240^{* *}$ & -0.116 & $0.163^{*}$ & -0.088 & 1 & \\
\hline $\mathbf{L E V}$ & -0.063 & -0.085 & -0.027 & $-0.136^{*}$ & 0.031 & 0.092 & 1 \\
\hline
\end{tabular}

Notes: ** Correlation is significant at level 0.01 (2- tailed)

** Correlation is significant at level 0.05 (2- tailed)

Table 4 shows the summary of Pearson correlation coefficients, and the results reveal that entire correlations are lower than 0.80, which agrees with the studies of (Gujarati \& Porter, 2009) that correlation matrix shouldn't be more than (0.80) to ensure the absence of multicollinearity issue. Table 4 shows also the results of correlation matrix, for all main variables and related control variables used in the corporate value models. In this study, the correlation matrix shows that multicollinearity isn't a problem, where the highest pair correlation between variables is $(78.7 \%)$, which occurred between $\mathrm{AC}_{\text {SIZE }}$ and $\mathrm{AC}_{\mathrm{ACTIV}}$. In the model, the correlation matrix shows that inclusion of all independent variables shouldn't lead to a multicollinearity problem. In the pair correlation matrix, the results of all independent variables with ROA showed a significant correlation between all of them, and according to the correlation between ROA and related control variables, ROA is significantly correlated with all of the control variables. Furthermore, variables' tolerance values are listed in table (5) below, where all of those values are greater than (0.1) and all VIF values are lower than (10), as proposed by the study of (Hair, et al., 2010), which mean that both variables' tolerance values and VIF values agree with the recommended range, and therefore it indicate the non-existance of multicollinearity issue.

\subsubsection{Multicollinearity}

The most commonly used methods to measure degree of multicollinearity independent with other independent variables, in a regression model are variance inflation factor (VIF) and Tolerance value (O'Brien, 2007), knowing that multicollinearity problem occurs in case where the (VIF) value for each variable is more than (10), in addition the tolerance value for the variables was less than (1). Table 5 shows the non-existance of multicollinearity issue or problem between the independent variables and other independent variables in the corporate value models.

Table 5. Multicollinearity test for corporate value model

\begin{tabular}{lll}
\hline Variables & VIF & Tolerance Value \\
\hline $\mathbf{A C}_{\text {SIZE }}$ & 2.74 & 0.36 \\
\hline $\mathbf{A C}_{\text {IND }}$ & 1.05 & 0.94 \\
\hline $\mathbf{A C}_{\text {ACTIV }}$ & 2.63 & 0.38 \\
\hline $\mathbf{A C}_{\text {EXPER }}$ & 1.19 & 0.84 \\
\hline $\mathbf{F}_{\text {SIZE }}$ & 1.09 & 0.91 \\
\hline LEV & 1.03 & 0.96 \\
\hline
\end{tabular}




\subsubsection{Regression Results of Corporate Value Model (Based on ROA)}

Table 6. Multiple linear regression for the effect of auditing committee characteristics on corporate value enhancement

\begin{tabular}{llll}
\hline Variable & Coefficient & t- Statistic & Sig. \\
\hline Constant & & -6.833 & 0.000 \\
\hline $\mathbf{A C}_{\text {SIZE }}$ & 0.327 & 2.264 & 0.025 \\
\hline $\mathbf{A C}_{\text {IND }}$ & 0.204 & 3.759 & 0.000 \\
\hline $\mathbf{A C}_{\text {ACTIV }}$ & 0.183 & 2.134 & 0.034 \\
\hline $\mathbf{A C}_{\text {EXPER }}$ & -0.008 & -0.305 & 0.761 \\
\hline $\mathbf{F}_{\text {SIZE }}$ & 0.386 & 7.00 & 0.000 \\
\hline LEV & -0.053 & -0.984 & 0.326 \\
\hline $\mathbf{R}^{2}$ & 0.385 & & \\
\hline Adjusted R & & \\
\hline Sig. (F-Statistic) & 0.374 & & \\
\hline F- Statistics & 0.000 & & \\
\hline Durbin Watson Statistics & 4.552 & \\
\hline
\end{tabular}

The regression results of ROA are presented in Table 6 with $\mathrm{R}^{2}$ value $=0.385$, which indicate that model explains (38.5\%) of the variance in the corporate performance, as measured by ROA, and it's a respectable result, where the adjusted $\mathrm{R}^{2}$ coefficient of the determination equal to $(37.4 \%)$ of the variation in the dependent variable, and explained by the independent variable's variations. This indicates that corporate performance variation measured by ROA, was statistically explained through the equation, where Table 6 shows that Prob (F-statistics) at ( $\mathrm{F}=4.552$, $\mathrm{p}<0.000$ ), which is statistically significance value of the model. Durbin-Watson (DW) test is also used as a statistical test to detect any autocorrelation, where the acceptable range of Durbin-Watson should be between (1.5-2.5) (Kazmier, 1996), and is consistent with the result of Durbin-Watson (DW) statistics of (1.613), at Table 6 which indicate no autocorrelation issue.

In regard to testing the relationship between auditing committee size and company's value, it shows through the analysis of regression model results the existance of a statistically positive significant relationship between the size of auditing committee and company's value, where the coefficient value amounted to $(0.327, \mathrm{p}=0.025)$, which support the first hypothesis (H1), and these results show that the greater number of auditing committee members, the greater the company's value. This result align with the results of some previous studies, like (DakhlAllah, et al, 2020; Aldamen, et al., 2012 \& Walker, 2004), where the higher the number of auditing committee members the more the diversity of skills and knowledge, which may reflect positively on the company's performance and its market value. But in regard to testing the relationship between auditing committee independence and company's value, it shows through the analysis of regression model results existence of a statistically positive significant relationship between the independence of auditing committee and company's value, where the coefficient value amounted to (0.204, $\mathrm{p}=$ $0.000)$, which support the second hypothesis ( $\mathrm{H} 2)$, and this result align with the results of some previous studies, like (Kallamu, et al.2015, Sommer, 1991 and Chan \& Li, 2008), while in regard to testing the relationship between auditing committee activities and company's value, it shows through the analysis of regression model results the existance of statistically positive significant relationship between the activities of auditing committee and company's value, where the coefficient value amounted to $(0.183, \mathrm{p}=0.034)$ and this support the third hypothesis $(\mathrm{H} 3)$, and align with the results of some previous studies, like (Al-Farooque, et al., 2019, Sharma, et al., 2009 \& Choi, et al., 2013), which stated that members of the auditing committee do meet continuously and repeatedly, where the greater the frequency of meetings the greater the performance and value of company, and in regard to testing the relationship between auditing committee financial and accounting expertise and company's value, and it shows through the analysis of regression model results the non-existance of statistically positive significant relationship between the financial and accounting expertise of auditing committee and company's value, where the coefficient value amounted 
to $(-0.008, p=0.761)$ and this reject the forth hypothesis $(\mathrm{H} 4)$, and this result align with the results of some previous studies, like (DakhlAllah, et al, 2020 ; Chan \& Li, 2008).

It shows through the analysis of regression model results the existence of statistically significant positive relationship between firm size as the controlling variable and the corporate value, where the coefficient value amounted to $(0.386$, $\mathrm{p}=0.000$ ). It also shows the non-existence of a statistically significant positive relationship between leverage as the controlling variable and the corporate value, where the coefficient value amounted to $(-0.053, p=0.326)$.

\section{Conclusions}

This study examined the effect of $\mathrm{AC}$ characteristics (size, independence, activities, and experience) on the corporate value (ROA) at the Jordanian industrial companies listed in ASE, which amounted to (47), during the five years period between (2014-2018), and as mentioned earlier, the motive behind this study is the gap in the theoretical literature and previous studies represented in the lack of evidence related to this topic in non-developed countries, such as Jordan. This study also adds to the understanding of auditing committee characteristics which influence the enhancement of corporate value, especially with the unique Jordanian industrial culture and environment.

Despite the consistency of this study with previous studies which have examined the integration between the AC characteristics and its relationship with the quality of financial reports and earnings management, but it consider a unique one due to the fact that it added the integration of auditing committee characteristics to enhance the corporate value inside and outside the Jordanian market, since it play an important role in the encouragement of all listed Jordanian industrial companies to enhance and strengthen its value, in order to create a strong infrastructure for investments.

Therefore, the study results showed a positive statistical relationship between all the AC characteristics (size, activities, independence) on the corporate value at the Jordanian industrial companies, with the exception of AC financial experience which didn't have a relationship with the company's value. This relationship comes as a result of activating the corporate governance rules by the Jordanian public shareholding industrial companies, which stated that every Jordanian public shareholding must set up an auditing committee that enjoy certain characteristics, such as size, independence, and number of meetings, and taking into consideration that enhancement of corporate value would be recognized and viewed by investors and stakeholders as indication on corporate success.

\section{Recommendations \& Suggestions for Future Researches}

This study examined the relationship between the characteristics of auditing committee and corporate value, therefore this study recommend the following:

- Researcher proposes to study this relationship in the future with the board of director's characteristics, in order to enhance corporate value.

- This study consider ROA as one of the appropriate accounting criteria to measure the corporate value, and therefore the upcoming studies should use more of the other market and economic criteria, such as Tobin's Q and added economical value to measure the corporate value.

- This study was limited to the analysis of five years data at the Jordanian industrial companies, therefore this study suggest to conduct the future researches that will extend the period of this study sample to additional years and in other sectors, such as the service and financial sectors, in order to cover the other sectors in those studies, for the purpose of raising the efficiency of national economy.

- Given the relationship between corporate governance and corporate value in the current literature, researchers and academics must address in their future researches some of the other variables, such as the diversity of board of directors, disclosure, transparency, and auditing fees in order to enhance the corporate performance and value.

\section{References}

Abbott, L. J., Parker, S., \& Peters, G. F. (2004). Auditing committee characteristics and restatements. Auditing: A Journal of Practice \& Theory, 23(1), 69-87. https://doi.org/10.2308/aud.2004.23.1.69

Afza, T., \& Nazir, M. S. (2014). Auditing quality and firm value: A case of Pakistan. Research Journal of Applied Sciences, Engineering and Technology, 7(9), 1803-1810. https://doi.org/10.19026/rjaset.7.465

Al-Farooque, O., Buachoom, W., \& Sun, L. (2019). Board, auditing committee, ownership and financial performance emerging trends from Thailand. Pacific Accounting Review, 32(1), 54-81. https://doi.org/10.1108/PAR-10-2018-0079

Aldamen, H., Duncan, K., Kelly, S., McNamara, R., \& Nagel, S. (2012). Auditing committee characteristics and firm 
performance during the global financial crisis. Accounting \& Finance, 52(4), 971-1000. https://doi.org/10.1111/j.1467-629X.2011.00447.x

Al-Karasneh, H., \& Bataineh, A. (2018). Does Corporate Governance Reduce Agency Costs in the Jordanian Industrial Companies?. International Review of Management and Business Research, 7(2), 615-625. https://doi.org/10.30543/7-2(2018)-29

Al-Matari, E. M., Al-Swidi, A. K., \& Fadzil, F. H. B. (2014). Auditing committee characteristics and executive committee characteristics and firm performance in Oman: empirical study. Asian Social Science, 10(12), 98. https://doi.org/10.5539/ass.v10n12p98

Al-Thuneibat, A. (2006). The Auditing: The Light of International Auditing Standards and Local Laws and Regulations: Theory and Application (1st ed.). University of Jordan.

Arens, A. A., Elder, R. J., \& Beasley, M. S. (2009). Auditing and Assurance Services: An Integrated Approach (13th ed.). New Jersey: Prentice Hall, USA.

Bataineh, A. (2018). The Effect of Using Computerized Accounting Information Systems on Reducing Production Costs in Jordanian Pharmaceutical Companies. International Journal of Business and Management Invention (IJBMI), 7(7), 1-10.

Beasley, M. S., \& Salterio, S. E. (2001). The relationship between characteristics and voluntary improvements in auditing committee composition and experience. Contemporary Accounting Research, 18(4), 539-70. https://doi.org/10.1506/RM1J-A0YM-3VMV-TAMV

Bedard, J., Chtourou, S. M., \& Courteau, L. (2004). The effect of auditing committee expertise, independence, and activity on aggressive earnings management. Journal of Practice \& Theory, 23, 13-35. https://doi.org/10.2308/aud.2004.23.2.13

Bhagat, S., \& Jefferis, R. H. (2005). The Econometrics of Corporate Governance Studies. Mit Press.

Bolton, B. (2014). Auditing committee performance: ownership vs. independence-Did SOX gets it wrong?. Accounting \& Finance, 54(1), 83-112. https://doi.org/10.1111/j.1467-629X.2012.00504.X

Chan, K. C., \& Li, J. (2008). Auditing committee and firm value: evidence on outside top executives as expert-independent directors. Corporate Governance: An International Review, 16(1), 16-31. https://doi.org/10.1111/j.1467-8683.2008.00662.x

Chen, J., Duh, R. R., \& Shiue, F. N. (2008). The effect of auditing committees on earnings-return association: Evidence from foreign registrants in the United States. Corporate Governance, International Review, 16(1), 32-40. https://doi.org/10.1111/j.1467-8683.2008.00660.x

Choi, J. J., Lam, K. C., Sami, H., \& Zhou, H. (2013). Foreign ownership and information asymmetry. Asia-Pacific Journal of Financial Studies, 42(2), 141-166. https://doi.org/10.1111/ajfs.12010

DakhlAllah, M. M., Rashid, N., Abdullah, W. A. W., \& Al Shehab, H. J. (2020). Auditing Committee and Tobin's Q as A Measure of Firm Performance among Jordanian Companies. Jour of Adv Research in Dynamical \& Control Systems, 12(1). https://doi.org/10.5373/JARDCS/V12I1/20201005

DeZoort, F. T., Houston, R. W., \& Hermanson, D. R. (2003). Auditing committee member support for proposed auditing adjustments: A source credibility perspective. Journal of Practice \& Theory, 22(2), 189-205. https://doi.org/10.2308/aud.2003.22.2.189

Fama, E. F., \& Jensen, M. C. (1983). Separation of ownership and control. Journal of Law and Economics, 26(2), 301-325. https://doi.org/10.1086/467037

Felo, A. J., Krishnamurthy, S., \& Solieri, S. A. (2003). Auditing committee characteristics and the perceived quality financial reporting: An empirical analysis. Working Paper Series, Graduate School of Professional Studies, Penn State University, Great Valley, Malvern PA. https://doi.org/10.2139/ssrn.401240

Financial Reporting Council. (2008). Promoting auditing quality, Auditing Quality Framework. Retrieved May 5, 2012, https://www.frc.org.uk/Our-Work/Publications/FRC-Board/The-Auditing-Quality-Framework-(1)-File.pdf

García-Sánchez, I. M., Frias-Aceituno, J. V., \& Garcia-Rubio, R. (2012). Determining factors of auditing committee attributes: Evidence from Spain. International Journal of Auditing, 16(2), 184-213. https://doi.org/10.1111/j.1099-1123.2012.00451.x 
Ghafran, C., \& O'Sullivan, N. (2013). The governance role of auditing committees: reviewing a decade of evidence. International Journal of Management Reviews, 15(4), 381-407.

Ghosh, A., Marra, A., \& Moon, D. (2010). Corporate boards, auditing committees, and earnings management: Preand post-SOX evidence. Journal of Business Finance \& Accounting, 37, 1145-1176. https://doi.org/10.1111/j.1468-5957.2010.02218.x

Gujarati, D., \& Porter, D. (2009). Basic Econometrics (5th ed.). International Edition, McGraw Hill.

Hair, J. F., Tatham, R. L., Anderson, R. E., \& Black, W. (2006). Multivariate data analysis (Vol. 6). Pearson Prentice Hall Upper Saddle River, NJ.

Hamdan, A., Al-Hayale, T., \& Aboagela, E. (2012). The impact of auditing committee characteristics on accounting conservatism: Additional evidence from Jordan. Journal of King Saud University, 24(1), 1-15. https://doi.org/10.2139/ssrn.2130354

Heenetigala, K., \& Armstrong, A. F. (2011, December). The impact of corporate governance on firm performance in an unstable economic and political environment: Evidence from Sri Lanka. 2012 Financial markets \& corporate governance conference. https://doi.org/10.2139/ssrn.1971927

Ilona, D. (2008). Board quality and firm performance. Master Dissertation, University Utara Malaysia.

Ismail, H., Iskandar, T. M., \& Rahmat, M. M. (2008). Corporate reporting quality, auditing committee and quality of auditing. Malaysian Accounting Review, 7(1). 21-43.

Kallamu, B., \& Saat, N. (2015). Auditing committee attributes and firm performance: evidence from Malaysian finance companies. Asian Review of Accounting, 23(3), 206-231. https://doi.org/10.1108/ARA-11-2013-0076

Kazmier, L. (1996). Schaum's Outline of Theory and Problems of Business Statistics. McGraw-Hill.

Krishnan, J. (2005). Auditing committee quality and internal control: An empirical analysis. Accounting Review, 80(2), 649-675. https://doi.org/10.2308/accr.2005.80.2.649

Mintah, P., \& Schadewitz, H. (2018). Auditing committee adoption and firm value: evidence from UK financial institutions. International Journal of Accounting \& Information Management, 26(1), 205-226.

O'Brien, R. M. (2007). A caution regarding rules of thumb for variance inflation factors, Quality \& quantity. https://doi.org/10.1007/s11135-006-9018-6

Persons, O. S. (2005). The relation between the new corporate governance rules and the likelihood of financial statement fraud. Review of Accounting \& Finance, 4(2), 125-148. https://doi.org/10.1108/eb043426

Ramsay, I. M. (2001). Independence of Australian Company Auditors: Review of Current Australian Requirements and Proposals for Reform: Report to the Minister for Financial Services and Regulation. Corporate Governance and Accounting Policy Division, Department of the Treasury. https://doi.org/10.2139/ssrn.298122

Redenbach, M. (2013). Incentive for the Auditing Committee to Signal their Monitoring Activities using Voluntary Disclosure in the Auditing Committee Report. PhD thesis, Drexel University.

Sarbanes-Oxiey Act of 2002. (2002). Retrieved April 16, 2005, from http://www.pcaobus.org/AboutUs/SarbanesOxley Act of_2002.pdf

Sharma, V., Naiker, V., \& Lee, B. (2009). Determinants of auditing committee meeting frequency: Evidence from a voluntary governance system. Accounting Horizons, 23(3), 245-263. https://doi.org/10.2308/acch.2009.23.3.245

Smith, R. (2003). Auditing committees combined code guidance. London, Financial Reporting Council.

Soliman, M. M., \& Ragab, A. A. (2014). Auditing committee effectiveness, auditing quality and earnings management: an empirical study of the listed companies in Egypt. Research Journal of Finance and Accounting, 5(2), 155-166.

Sommer, A. A. Jr. (1991, June). Auditing committees: an educational opportunity for auditors. Accounting Horizons, 91-93.

Walker, R. (2004). Gaps in Guidelines on Auditing Committees. Abacus, 40(2), 157-192. https://doi.org/10.1111/j.1467-6281.2004.00156.x

Xie, B., Davidson III, W. N., \& DaDalt, P. J. (2003). Earnings management and corporate governance: the role of the board and the auditing committee. Journal of Corporate Finance, 9(3), 295-316. https://doi.org/10.1016/S0929-1199(02)00006-8 